\title{
Efektivitas Penerapan Model Probing-Prompting Ditinjau Dari Kemampuan Berpikir Kritis Siswa
}

\author{
Muhamad Ruslan Layn \\ Fakultas Keguruan dan Ilmu Pendidikan Universitas Muhammadiyah Sorong \\ Email: ruslanlayn56@gmail.com
}

\begin{abstract}
Abstrak
Penelitian ini bertujuan untuk mengetahui efektivitas penerapan model probing-prompting ditinjau dari kemampuan berpikir kritis siswa. Populasi penelitian ini adalah seluruh siswa kelas VIII SMP Negeri 9 Kota Sorong tahun pelajaran 2017/2018 yang terdiri dari 8 kelas. Sampel penelitian ini adalah siswa kelas VIII-C yang dipilih dengan teknik purposive sampling. Desain penelitian ini adalah one shot case study. Instrumen penelitian ini adalah tes uraian berpikir kritis. Berdasarkan hasil analisis data, persentase siswa yang memiliki kemampuan berpikir kritis dengan baik kurang dari 65\%. Dengan demikian, model probing-prompting tidak efektif ditinjau dari kemampuan berpikir kritis siswa.
\end{abstract}

Kata kunci: Berpikir kritis; Efektivitas Pembelajaran; Probing-Prompting

\section{The Effectiveness of Implementation of Probing-Prompting Model Viewed From Student's Critical Thinking Ability}

\begin{abstract}
Abtract
This research aimed to know the effectiveness of probing-rompting model viewed by students critical thinking ability. The population of this research was all students of grade VIII of SMP Negeri 9 Kota Sorong in academic years of 2017/2018 that consist of 8 classes. The sample of this research was students of VIII-C which was taken by purposive sampling technique. This research design was one shot case study. Instrument of this research was essay test of critical thinking. Based on the analysis of data, the percentage of students who have good critical thinking ability was less than $65 \%$. Thus, probingprompting model was less effective viewed by critical thinking ability.
\end{abstract}

Keywords: Critical thinking; Learning effectiveness; Probing-Prompting 


\section{PENDAHULUAN}

Kurikulum 2013 merupakan sebuah kurikulum yang dirancang agar siswa mampu memiliki kompentensi sikap, pengetahuan, dan keterampilan sehingga dapat menjadi pribadi dan warga negara yang produktif, kritis, kreatif, dan inovatif. pemahaman dan disposisi matematik merupakan kompetensi esensial yang harus dimiliki siswa, seperti yang termuat dalam kompetensi inti kurikulum matematika 2013.

Martin, dkk., 2008 Dalam proses pembelajaran dikelas, terdapat sejumlah mata pelajaran pokok diantaranya adalah matematika. Namun, hasil riset dari Trends in International Mathematics and Science Study (TIMSS) menjelaskan bahwa terdapat kemampuan siswa kelas 2 SMP di Indonesia masih berada dibawah rata-rata internasional. Hal ini memperlihatkan masih rendahnya prestasi matematika siswa Indonesia.

Faktor yang menjadi penyebab rendahnya hasil belajar matematika siswa adalah rendahnya kemampuan berpikir kritis siswa. Hal ini dijelaskan oleh Wahyudin (dalam Herawati, 2006:4) rendahnya hasil belajar atau prestasi siswa disebabkan upaya pengembangan kemampuan berpikir kritis disekolah yang jarang dioptimalkan secara berkelanjutan sehingga membuat keterampilan berpikir kritis siswa sangat kurang. Rendahnya kemampuan berpikir kritis siswa tidak terlepas dari bagaimana pembelajaran matematika itu berlangsung. Marjohan (Nugraha,2012:19) menyatakan bahwa system pembelajaranyang diterapkan oleh guru hanya mengulang-ulang serta sangat minim kreativitas dalam mengembangkan pelajaran dan seni mengajar. Guru sebagai fasilitator harus mampu memilih model pembelajaran matematika yang memberi-kan siswa kesempatan untuk berpikir seluas-luasnya, salahsatunyaadalah model probing-prompting.

Pandangan konstruktifisme menjelaskan bahwa salah satu pendekatan pembelajaran dapat meningkatkan aktivitas berpikir dan mengembangkan disposisi matematik Prompting. Suherman (2008:23) mengemukakan bahwa teknik Probing Prompting adalah pembelajaran dengan cara menyajikan serangkaian pertanyaan yang sifatnya menuntun dan menggali sehingga terjadi proses berpikir yang mengaitkan pengetahuan dan pengalaman sebelumnya dengan pengetahuan baru yang akan dipelajari. Pertanyaan-pertanyaan yang dilontarkan pada siswa mendorong siswa berpikir lebihrasional tentang pengetahuan yang telah diperoleh sebelumnya, dan mengaitkan pertanyaanpertanyaan berikutnya sehingga timbul pengetahuan baru. Melalui kondisi seperti itu siswa berlatih melaksanakan pemahaman matematik yang bermakna (meaningful mathematical understanding) serta menunjukkan perilaku disposisi matematik.

Saat ini salah satu kemampuan berpikir yang harus dimiliki oleh siswa adalah kemampuan berpikir kritis. Tahapan berpikir kritis menurut Arief 'kemampuan siswa dalam menganalisis, menyintesis, memecahkan masalah, membuat kesimpulan dan membuat evaluasi' (Susanto, 2013, hlm. 129). Berkaitan dengan pendapat tersebut Munir mengungkapkan tujuan pembelajaran matematika di Sekolah Dasar adalah 'membekali anak didik dengan kemampuan mengidentifikasi, menganalisis, dan menyusun alternatif pemecahan masalah sosial yang terjadi dalam kehidupan masyarakat'. (Susanto, 2013, hlm. 151). Oleh karena itu pembelajaran matematika harus diarahkan pada pengembangan kemampuan berpikir kritis, namun prosesnya akan sukar jika pembelajaran masih terpusat pada guru sehingga perlu adanya suatu metode pembelajaran yang dapat membantu guru untuk mengembangkan kemampuan berpikir kritis pada siswa. Adapun metode yang diharapkan dapat membantu siswa meningkatkan kemampuan berpikir kritis pada pembelajaran matematika adalah probing prompting.

Menurut Sudarti (Huda, Miftahul 2013, hal. 282) terdapat 7 tahapan probing prompting yaitu 1) Menghadapkan siswa pada situasi baru melalui gambar atau teks yang memiliki permasalahan, 2) waktu tunggu, 3) Mengajukan pertanyaan sesuai tujuan pembelajaran, 4) Waktu tunggu 5) Konfirmasi jawaban, 6) Tanggapan jawaban dan 7) Mengajukan pertanyaan akhir.

Perlu kiranya diteliti lebih lanjut, apakah model probing-prompting efektif ditinjau dari kemampuan berpikir kritis dalam pembelajaran matematika. Olehkarena itu, dilakukan penelitian pada siswa kelas VIII SMP Negeri 9 Kota Sorong tahun pelajaran 2017/2018. Penelitian ini bertujuan untuk mengetahui 
efektivitas penerapan model probing-prompting ditinjau dari kemampuan berpikir kritis siswa SMP Negeri 9 Kota Sorong.

\section{METODE PENELITIAN}

Populasi penelitian ini adalah seluruh siswa kelas VIII semester genap SMP Negeri 9 Kota Sorong tahun pelajaran 2017/2018, terdiri dari8 kelas yaitu kelas VIII A - VIII H. Sampel dipilih dengan teknik purposive sampling, setelah berdiskusi dengan guru mitra, terpilihlah kelas VIII-C sebagai sampel penelitian. Desain penelitian ini adalah one shot case study, menggunakan satu kelompok dengan diberi satu kali perlakuan dan satu kali pengukuran. Data penelitian ini adalah skor kemampuan berpikir kritis berupa data kuantitatif yang diperoleh melalui tes kemampuan berpikir kritis yang diberikan kepada siswa setelah mengikuti pembelajaran dengan model probingprompting. Sebelum digunakan, terlebih dahulu instrument diuji coba untuk mengetahui validitas, reliabilitas, indeks kesukaran, dan daya pembedanya. Setelah dilakukan uji coba, instrument dinyatakan valid dan memiliki reliabilitas tinggi dengan harga koefisien reliabilitas 0,65 . Soal yang digunakan memiliki indeks kesukaran sukar dan sedang, serta memiliki indeks daya pembeda baik dan sedang.Data skor kemampuan berpikir kritis siswa dianalisis menggunakan uji proporsi.

\section{HASIL DAN PEMBAHASAN}

Setelah dilakukan analisis data hasil tes berpikir kritis, diperoleh 5 siswa yang mendapatkan nilai lebih dari atau sama dengan 72 dari 34 siswa. Dengan demikian persentase siswa yang memiliki kemampuan berpikir kritis dengan baik adalah $8,94 \%$. Berdasarkan hasil uji proporsi untuk data kemampuan berpikir kritis diperoleh $Z_{\text {hitung }}<Z_{\text {tabelyang berarti }} \mathrm{H}_{0}$ diterima, maka proporsi siswa yang memiliki kemampuan berpikir kritis dengan baik kurang dari $65 \%$. Berdasarkan analisisdata pencapaian indicator kemampuan berpikir kritis siswa, diketahui bahwa rata-rata pencapaian indikator kemampuan berpikir kritis siswa yang memperoleh pembelajaran dengan model probing-prompting adalah 48,50\%. Indikator berpikir kritis yang paling baik dicapai siswa adalah menganalisis argumen, yaitu sebesar
$53,20 \%$.

Berdasarkan hasil analisis dan uji hipotesis data kemampuan berpikir kritis siswa, diketahui bahwa model probing-prompting tidak efektif ditinjau dari kemampuan berpikir kritis siswa karena persentase siswa yang memiliki kemampuan berpikir kritis dengan baik tidak lebih dari $65 \%$. Salah satu peneliti yang telah melakukan penelitian tentang model probing-prompting sebelumnya adalah Muflihin (2010: 64) yang menyimpulkan bahwa peningkatan kemampuan berpikir kritis siswa SMP yang pembelajarannya menggunakan teknik probing-prompting tidak lebih baik daripada siswa SMP yang pembelajarannya secara konvensional.

Simpulan penelitian tersebut menunjukkan bahwa probing-prompting tidak efektif untuk meningkatkan kemampuan berpikir kritis siswa. Pada pelaksanaan pembelajaran, siswa terlihat tegang dengan pertanyaan-pertanyaan yang diajukan oleh guru karna mereka tidak bisa menjawab. Guru memiliki kendala untuk menuntun siswa mendapatkan jawaban yang benar, karna siswa kurang menguasai materi prasyarat, yaitu sistem persamaan linear satu variabel (SPLSV). Siswa juga tidak memahami materi yang telah dipelajari sebelumnya, seperti aljabar dan segiempat. Hal ini terlihat dari ketidakmampuan siswa menjawab pertanyaan guru mengenai penjumlahan aljabar dan keliling persegi panjang.

Kendala tersebut juga terjadi pada saat mengerjakan LKS, sehingga kondisi kelas menjadi tidak kondusif karena siswa sibuk bertanya dan berdiskusi dengan siswa dari kelompok lain. Beberapa siswa juga terlihat tidak membantu teman sekelompoknya mengerjakan LKS, siswa sibuk melakukan kegiatan yang tidak berkaitan dengan pembelajaran. Untuk mengatasinya, guru berkeliling kelas untuk mengawasi jalannya diskusi dan membantu siswa yang kesulitan.

Kendala lain timbul saat tahap presentasi, banyak siswa yang enggan maju ke depan kelas untuk mempresentasikan hasil diskusi kelompoknya karena alasan tidak siap. Hal ini menyita banyak waktu, untuk mengatasinya guru meminta masing-masing kelompok untuk menunjuk wakil tiap kelompok dari awal diskusi, sehingga siswa bisa mempersiapkan diri untuk mempresentasikan 
hasil diskusi kelompoknya.

Kendala terakhir adalah waktu yang terbatas, menyebabkan pembahasan materi yang kurang maksimal. Akibatnya, siswa yang memiliki kemampuan rendah tidak dapat memahami materi yang telah dibahas sehingga kesulitan untuk mengikuti materi yang akan dibahas pada pertemuan selanjutnya. Hal ini terjadi karena masalah yang disajikan pada model probing-prompting merupakan masalah yang membutuhkan kemampuan berpikir cukup tinggi, sehingga umumnya yang dapat mengikuti model pembelajaran ini dengan baik adalah siswa yang tergolong berkemampuan tingkat tinggi pula. Namun peneliti selalu berusaha untuk meminimalisirkan kendalakendala tersebut dengan mengevaluasi tiap pertemuan, seperti mengevaluasi LKS, dan pertanyaan-pertanyaan yang akan diajukan kepada siswa.

Kendala-kendala tersebut dapat mempengaruhi hasil akhir belajar siswa. Terlihat saat siswa mengerjakan tes kemampuan berpikir kritis, banyak siswa yang kesulitan untuk menuliskan jawabannya, terutama pada siswa yang memiliki kemampuan rendah. Siswa sudah terbiasa pada proses pembelajaran konvesional dan soal-soal yang bersifat rutin sehingga membuat pengetahuan siswa sebatas apa yang telah disampaikan guru dan soal-soal yang sudah biasa mereka kerjakan.

\section{KESIMPULAN}

Berdasarkan pembahasan diperoleh simpulan bahwa model probing-prompting tidak efektif ditinjau dari kemampuan berpikir kritis siswa kelas VIII SMP Negeri 9 Kota Sorong tahun pelajaran 2017/2018.

\section{DAFTAR PUSTAKA}

Herawati, C. (2006). Pembelajaran Matematika Melalui Pendekatan Reciprocal Teaching dalam Upaya Meningkatkan Kemampuan Berpikir Kritis Siswa SMP. Skripsi. Bandung: UPI.

Martin, Xavier Sala., dkk. (2008). The Competitiveness Index: Measuring the Productive Potential of Nations. Dalam The Global Competitiveness Report 2008-2009
Muflihin. (2010). Pembelajaran Matematika dengan Teknik Probing-Prompting untuk Meningkatkan Kemampuan Berpikir Kritis Siswa SMP. Skripsi. Bandung: UPI.

Nugraha, A. Yuniarsa. (2012). Pengembangan Model Bahan Ajar Strategi Pembelajaran Konflik Kognitif (Cognitive Conflict) untuk Meningkatkan Kemampuan Pemecahan Masalah Matematis Siswa SMP. Skripsi. Bandung: UPI.

Suherman, Erman. (2008). Belajar dan Pembelajaran Matematika. Hand Out. Bandung: UPI. 